\title{
DESCRIPTION OF DATA CONSOLIDATION PROCESS OF THE CONDITION MONITORING OF ROAD NETWORK IN THE INFORMATION ANALYSIS SYSTEM
}

\author{
Andrii Sidliarenko \\ Commercial Director, LLC Antyplagiat, Ukraine \\ e-mail: a.sidliarenko@unicheck.com,orcid.org/0000-0002-5130-7657 \\ Iryna Myronets \\ Ph.D., Associate Professor, Associate Professor at the Department of Information Security \\ and Computer Engineering, Cherkasy State Technological University, Ukraine \\ e-mail: i.myronets@chdtu.edu.ua,orcid.org/0000-0003-2007-9943
}

\begin{abstract}
Summary
Information management and decision making in government geographically separated organizational systems are related to the collecting, storing and processing various information from various sources, data validating, actualizing and ensuring reliability, visualizing information and developing user-friendly interface for decision-makers. A significant volume and variety of data in reporting documentation create a crucial complexity of information analytical processing. The article discusses the structure of information flows that enter the information analytical system for monitoring the state of the road network and should be consolidated for future use. Creation and implementation of this information analytical system allow to maintain coordination and coherence of decisions based on data collected from various information sources and to control their implementation. This determines the relevance of the problem of ensuring the consolidation of physical, economic and social information about the state of the road infrastructure during the information analytical system monitoring of the state of the road network. The consolidated data is the initial information for the calculated mathematical models and is used to make decisions on the use of available resources and budget, assessing the condition of the road surface, optimizing the route of trucks.

Keywords: information management, state control of the road industry, data reliability, optimization of transport route, information processing, consistency of decisions.

DOI: https://doi.org/10.23856/4436

\section{Introduction}

Providing the completeness and integrity of information, that is used for condition monitoring of Ukraine road network, and which later becomes the basis for making managerial decisions at different organizational levels, is one of the major and important components of information management for government control of the roadway industry.

Information management and decision making in government geographically separated organizational systems are related to the collection, storage and reduction of diverse information from various sources, verification of data for validity, actualization and reliability, visualization of information and development of the convenient interface for decision makers. Active realization of control problems during the reduction process of big data is impossible without the implementation of modern information analysis systems (IAS) and decision support systems.
\end{abstract}


Among the tasks of information management for geographically distributed organizational systems are selected such management tasks, associated with the processing of mass data, as:

- information consolidation from different organizations (organizations related by the information flows, the organization low-level structures);

- data reliability (validity, accuracy, uniqueness);

- monitoring organization, gathering of relevant information;

- information security at each level of the geographically distributed system;

- technical and technological support of servers for storage and work with mass data.

When constructing the IAS for roadway control industry one of the most important problems is consolidating of data with various structures, data received of the existing systems and sources: regional units reporting, documents from governmental policy realization, internal plans and orders, information from other governmental and private organizations etc.

\section{Literature Analysis}

In modern business society the consolidated information within the management decision making is given a significant role. The methodology of information consolidation appears from the economic nature of business processes and from the reporting role as an information base for decision making and economic analysis (Isaev, 2006).

Many scientific works, of both native and foreign specialists, are devoted to the research of the problems of development and implementation of IAS into government work and their influence on regional development (Puhach, 2010; Order of the Cabinet of Ministers of Ukraine № 92-r of 11.02.2016; Yelchaninov, 2011; Sevastianova, 2009; Biriukov, 2012; Hritsenko, 2010; Buede, 2011; Zaslavskiy, 2010; Zaslavskiy, 2012; Makhno, 2012; Yudin, 2010).

For example, in the work (Puhach, 2010) the author draws attention to the chaos and absence of development strategy of information and analytical support of government managerial organizations, while the Concept of creating the integrated information analysis system "Transparent Budget" (Order of the Cabinet of Ministers of Ukraine № 92-r of 11.02.2016) refers to creating the IAS as a tool for modeling, predicting situations in the financial management sphere, process automation of reports making, facilitation for management decision making and checking for their effectiveness, analysis of regional development.

A significant amount and variety of data in reporting documentation create a crucial complexity of the information analytical processing. In the work (Biriukov, 2012) the authors proposed the software of the automated data processing and visualization of the roads condition. In the work (Gritsenko, 2010) is considered a decomposition designing scheme of IAS, which allows reducing the time of solving the designing tasks and provides support of the system structure in optimum form. It can also improve the quality of decisions made on the basis of database of this system.

The work (Buede, 2011) describes standard IDEF0, which is a federal information processing standard (FIPS), and was created by the U.S. government National Institute of Standards and Technologies (NIST).

Furthermore, in road industry for the IAS can be used data, which are geo-spatial information. The geo-spatial data representation is usable for the road network condition monitoring (Makhno, 2012), condition imaging of the objects construction and roadways repairing work (Yudin, 2010). 


\section{The Object of an Article}

The object of an article is presentation of the theoretical and methodological researches, practical bases of the data consolidating formation about physical characteristics of objects, economic and social information (condition of the facilities of road industry, their construction, reconstruction and repair, scopes and terms of funding, priority of governmental policy) and its implementation to the IAS of the condition monitoring of road network.

\section{Description of the Structure and Sources of Consolidated Data}

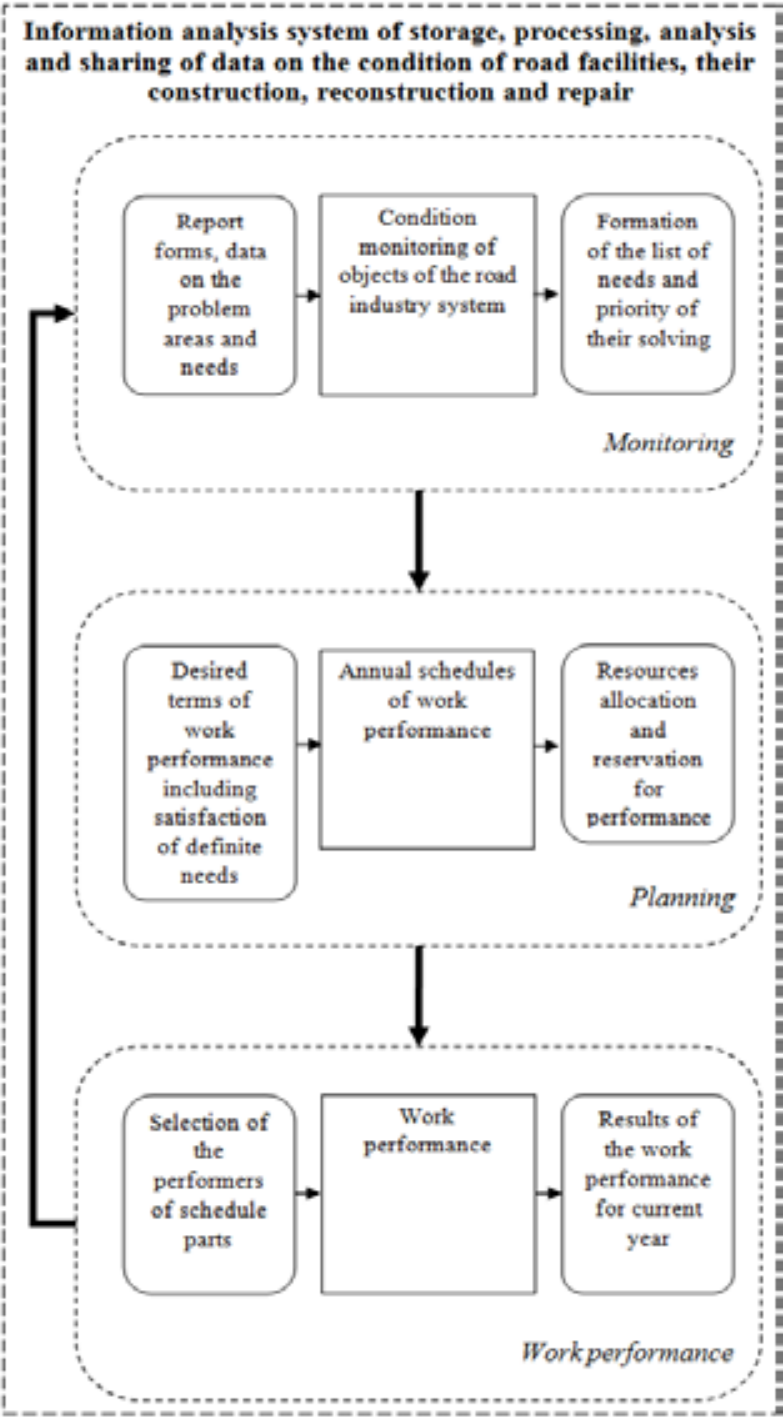

Fig. 1. The life cycle of work performances on the construction, reconstruction and repair of the road facilities
Creation and implementation of IAS allow to maintain coordination and coherence of decisions, based on data collected from various information sources, and to control their implementation. Consolidated data are used for the ensuring of management activities automation in government and allow improving the efficiency and quality of management decisions and business processes.

During the monitoring and analysis of road conditions, there occur a number of mathematical models that corresponds with the road management tasks. Such tasks may occur at every step of the life cycle of information, scientific and technical support of the monitoring and control processes of the road facilities condition (Fig. 1).

At the stage of monitoring in IAS are collected and analyzed different forms of reporting for all road facilities and is generated a comprehensive status report of the road industry. According to the results of detailed data analysis and comprehensive report, is compiled a list of tasks and works on construction, reconstruction and repair, a list of resources necessary for their realization, works timescales and their priority.

The data formed at the stage of monitoring are entrance data for the formation of schedule plan of works. According to the results of planning stage, is created a resources support 
plan for implementation of the works of construction, reconstruction and repair of road facilities, including the expected financial yield.

The stage of work performance involves full information support in schedule plan implementation upon each item - from the selection of performers, ending the presentation and analysis of the conducted works results - for basing them, for further use and comprehensive analysis at the stage of monitoring.

At every stage of the life cycle the data can come from various sources (regional service, government, operational analytical data, etc.) and have different structure and priority (Table 1).

Table 1

Information Flows for Analytical Processing at Different Stages of the Life Cycle

\begin{tabular}{|l|l|l|}
\hline $\begin{array}{l}\text { Stage of the } \\
\text { Life Cycle }\end{array}$ & Sources of Information Flows & \multicolumn{1}{c|}{ Forms of Data Submission } \\
\hline Monitoring & $\begin{array}{l}\text { Regional road services, Ukraine } \\
\text { Government roadway agency } \\
\text { departments, government, scien- } \\
\text { tific research institutes }\end{array}$ & $\begin{array}{l}\text { Annual reports from regional services and } \\
\text { Ukraine Government roadway agency depart- } \\
\text { ments about the condition of road facilities, } \\
\text { their construction, reconstruction and repair, } \\
\text { governmental development programs, scien- } \\
\text { tific analytical materials, scientific research } \\
\text { results on researching of road surface quality }\end{array}$ \\
\hline Planning & $\begin{array}{l}\text { Regional road services, Ukraine } \\
\text { Government roadway agency } \\
\text { departments, government, } \\
\text { Ministry of Infrastructure of } \\
\text { Ukraine, Cabinet of Ministers of } \\
\text { Ukraine }\end{array}$ & $\begin{array}{l}\text { Annual schedule and current work performance } \\
\text { plans, Ukraine Government roadway agency } \\
\text { management order, directions and orders of the } \\
\text { executive departments of government }\end{array}$ \\
\hline $\begin{array}{l}\text { Work } \\
\text { performance }\end{array}$ & Regional road services & Current reports, analytical reports \\
\hline
\end{tabular}

At the initial stage, according to the annual schedule, in the end of a year, is conducted the analysis and monitoring of the condition of road network facilities, which is accompanied by the reports receiving from all the regional services and operational information about implementation of the annual plan. According to the results of this information gathering, processing and consolidating, is created and filled the database for such indicators of the objects condition as:

- quantity of the objects, which need repair, reconstruction and their geographical arrangement;

- complexity of the repair and reconstruction on each object;

- priority of the work performance;

- needs for work performance;

- current condition of the tasks in hand.

At this time are also received data about annual funding plan from the governmental budget, attraction of investors, implementation of scientific and technological developments for further work planning.

After forming the list of objects, needs of work performance with them, objects priority and planned funding, is designed an annual schedule of work performances, which is consistent with regional services and governmental policy strategy in the road industry. 
Next is the stage of work performance, which is accompanied by variable reports, references, quality analysis work etc. Then, at the end of the calendar year, are conducted indicators monitoring and analysis again.

The information contained in IAS can be used for a management decision making on the production scheduling, production capacity developing and objects of production purpose, which have an industry-wide significance for the development strategy and improvement of the public road network, the governmental, purpose-oriented, comprehensive and social road industry development programs, providing with detailed assessment of the objects condition of construction, reconstruction, repair and maintenance work of the roadways. That is why, relying on the mass data and potential participants of the decision making and correcting, their qualitative characteristics should be provided at all stages of the life cycle of informative, scientific and technical support.

Data entered in the IAS, are characterized by the following indicators:

- reliability - data, entered in IAS by the responsible employees, should correspond to the real indicators;

- accuracy - data should be entered according to the format defined for these data by regulatory standards, reporting documentation forms and IAS settings;

- completeness - information should cover all the indicators and give comprehensive data in accordance with regulatory acts, reporting requirements and other reporting documents, where it will be used;

- timeliness - delivery of information within the time limits prescribed by work processes, regulatory documents, IAS settings etc.

\section{Conclusions}

The consolidated data is the initial information for the calculated mathematical models and is used to make decisions on the use of available resources and budget, assessing the condition of the road surface, optimizing the route of trucks etc.

In organizations included into the structure of the road industry system, there is already a significant quantity of segmental information resources with databases, containing information about condition of road network, materials, used for improving the road surface quality, and methods of their use etc. This results the importance of the problem of providing the consolidation of physical, economic and social information about the condition of the road infrastructure during the IAS monitoring the condition of the road network.

\section{References}

Biriukov, D. S., Zaslavskiy, V. A., Sidliarenko, A. I. (2012). Rozvytok i vprovadzhennia informatsiino-analitychnoho zabezpechennia $v$ sferi keruvannia avtodorozhnim hospodarstvom rehioniv [Development and implementation of information and analytical support in the field of road management of the regions]. Visnyk Skhidnoukrainskoho natsionalnoho universytetu imeni Volodymyra Dalia, 8 (179), ch. 2, 10-16. [in Ukrainian]

Buede, D. M. (2011). The engineering design of systems: Models and methods. John Wiley and Sons.

Gritsenko, V. I., Skurikhin, V. I., Korchinskaya, Z. A. (2010). Informatsionnaya tekhnologiya OSTAP $i$ yeyo primenenie $v$ administrativno-organizatsionnom upravlenyi [Information 
technology OSTAP and its application in administrative and organizational management]. USiM, 6, 3-8. [in Russian]

Isaev, D. V., Kravchenko, T. K. (2006). Avtomatizirovannye sistemy formirovaniia konsolidirovannoy finansovoy otchetnosti: uchebnoe posobie [Automated systems for the formation of consolidated financial statements: a tutorial]. Moscow. [in Russian]

Kontseptsii stvorennia intehrovanoi informatsiino-analitychnoi systemy "Prozoryi biudzhet" [Concepts of the creation of an integrated information and analytical system "Transparent budget"]. Retrieved from http://zakon5.rada.gov.ua/laws/show/92-2016-\%D1\%80. [in Ukrainian] Makhno, M. F., Sidliarenko, A. I. (2012, November 12-16). Geospatial data presentation of road infrastructure in Kherson region. The 2 nd international scientific conference of students and young scientists "Theoretical and Applied Aspects of Cybernetics (TAAC)". Kyiv, Ukraine, 47-49.

Puhach, A. O. (2010). Sutnist protsesu informatsiino-analitychnoho zabezpechennia orhaniv derzhavnoi vykonavchoi vlady $v$ Ukraini [The essence of the process of information-analytical security of the organs of the state executive authority in Ukraine]. Derzhavne upravlinnia: udoskonalennia ta rozvytok, 8. Retrieved from http://www.dy.nayka.com.ua/index.php?operation $=1 \&$ iid $=165$. [in Ukrainian]

Sevastianova, A. Ye. (2009). Informatsionno-analiticheskie sistemy v elektronnom pravitelstve regiona [Information and analytical systems in the electronic government of the region]. Region: ekonomika i sotsiologiya, 4, 211-227. [in Russian]

Yelchaninov, D. B. (2011). Uprovadzhennia systemolohichnykh metodiv u diialnist orhaniv derzhavnoi vlady Ukrainy [Introduction of systemological methods in the activituyi of state authorities of Ukraine]. Teoriia ta praktyka derzhavnoho upravlinnia, 3 (34). Retrieved from http://www.kbuapa.kharkov.ua/e-book/tpdu/2011-3/doc/1/05.pdf. [in Ukrainian]

Yudin, V. P., Podhorniy, V. I., Vasileva, L. A., Veremeenko, L. A., Tarasenko, A. V. (2010). Geoinformatsionnye printsipy upravleniia podvizhnym sostavom i monitoringa transportnykh obektov na dorogakh i generalnykh planakh gorodov [Geoinformation principles of rolling stock management and monitoring of transport facilities on the roads and master plans of cities]. Vostochno-evropeiskiy zhurnal peredovykh tekhnolohiy, 2/2 (44), 4-7. [in Russian]

Zaslavskiy, V. A. (2010, November 12-13). Systems approach for risk management in regional systems. Proceedings of the International Conference "Research \& Development as the Basis for Innovation in creating the competitive region". Podgorica, Montenegro, 107, 93-105.

Zaslavskiy V. A. (2012). Establishment of rational steps towards sustainable developments for Italy-Ukraine-Norway. Workshop "Towards the UN Conference Rio+20". Gazzetta Ambiente, XVIII (5), 139-144. 